\title{
PEMANFAATAN RANCANGAN WEBSITE PRESTASI SEKOLAH
}

\author{
Dede Wira Trise Putra ${ }^{1)}$, Hilhamid Febrianto ${ }^{2)}$ \\ Fakultas Teknik, Institut Teknologi Padang, Jl. Gajah Mada Kandis Nanggalo, Padang \\ email: dedewtp339@yahoo.com
}

\section{INTISARI}

Data prestasi merupakan salah satu indikator dalam memilih sekolah bagi orang tua siswa untuk melanjutkan studi anaknya. Sekolah dengan prestasi yang baik, diyakini memiliki kualitas pembelajaran yang baik. Data prestasi yang menjadi acuan dapatberupa data prestasi akademik dan non akademik. Sebaran informasi dapat dilakukan melalui website sekolah, namun tidak bisa dijadikan pembanding. Hal ini membuat diperlukannya sebuah website yang menampilkan data prestasi sekolah dan dikelola oleh Dinas Pendidikan. Data pada website juga bisa menjadi acuan bagi Dinas dalam melakukan pengembangan sekolah ke depannya. Website yang dirancang akan diujikan oleh pihak terkait, sehingga dapat dilihat kebermanfaatan website bagi penggunanya.

Kata Kunci : Prestasi, Sekolah, website, akademik, non-akademik

\section{ABSTRACT}

Performance data is one indicator in choosing a school for parents of students to continue their children's studies. Schools with good achievements are believed to have good learning quality. Performance data that are used as a reference can be in the form of academic and non-academic achievement data. Information distribution can be done through the school website, but cannot be used as a comparison. This makes the need for a website that displays school performance data and is managed by the Education Office. Data on the website can also be a reference for the Department in developing schools in the future. The website designed will be tested by related parties, so it can be seen the usefulness of the website for its users.

Keywords: Achievement, School, website, academic, non-academic

\section{PENDAHULUAN}

Prestasi sekolah merupakan salah satu tolak ukur dalam pemilihan untuk melanjutkan studi. Setiap sekolah memiliki prestasi di bidang akademik dan non-akademik yang beragam.
Penyampaian informasi mengenai prestasi dapat menjadi salah satu media promosi bagi sekolah [1].

Website sekolah sebagai media informasi sudah menyediakan informasi tentang sekolah, hanya saja informasi yang disampikan hanya sebatas sekolah 
yang bersangkutan dan tidak semua yang mencakup data prestasi. Maka untuk memperoleh informasi, setiap pengguna akan membuka setiap website untuk melihat setiap informasi prestasi yang tersedia.

Data prestasi sekolah juga menjadi salah satu data penting bagi Dinas Pendidikan sarana untuk mengevaluasi sekolah dalam meningkatkan kualitas akademik maupun non akademik[5]. Salah satu wilayah yang dapat dijakdikan sebagai acuan pada penelitian ini adalah Kabupaten Pesisir Selatan pada tingkat Sekolah Menengah Pertama. Permasalahan sebaran informasi yang belum ada terpusat, maka dirancang sebuah website yang dapat menjadi sumber informasi bagi pengguna[2].

Berdasarkan kondisi tersebut maka dirancang sebuah media berupa website yang dapat dijadikan sarana yang dapat memudahkan masyarakat mencari informasi khususnya tentang sekolah yang ada di Kabupaten Pesisir Selatan yang dapat menyajikan informasi tentang prestasi sekolah dengan mudah.

\section{METODE PENELITIAN}

Metode penelitian pada penelitian ini menggunakan tahapan pada gambar 1.1 berikut ini

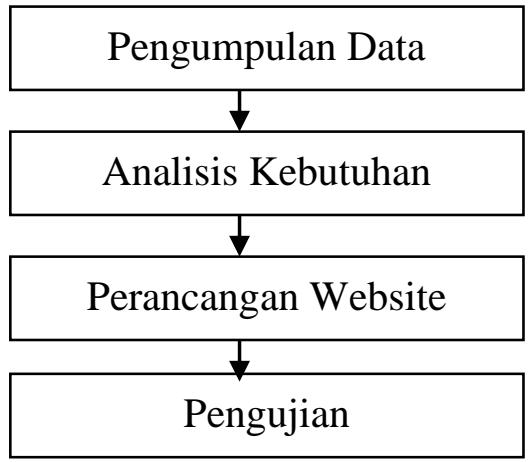

\section{Gambar 1 Tahapan Penelitian}

Gambar 1 merupakan tahapan yang dilakukan dalam penelitian ini dengan rincian :
1. Pengumpulan data yang dilakukan di Dinas Pendidikan untuk mendapatkan data presatasi sekolah dan dikelompokkan menjadi data akademik dan non-akademik

2. Analisis kebutuhan yang dilakukan dengan mengumpulkan kebutuhan yang terkait untuk digunakan dalam website yang dirancang

3. Perancangan website dilakukan dengan merancang pemodelan dan database yang dibutuhkan

4. Pengujian dengan melibatkan pengguna pada website

\section{CONTEXT DIAGRAM}

Context diagram merupakan salah satu cara dalam merepresentasikan sebuah sistem [3]. Context diagram dari website yang dirancang seperti terlihat pada gambar 1.2.

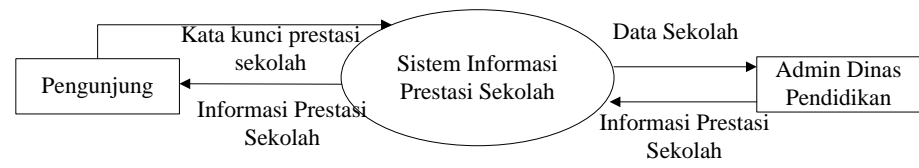

\section{Gambar 2 Context Diagram}

Gambar 2 memperlihatkan entity yang terlibat pada website ini adalah :

1. Admin Dinas Pendidikan yang dapat mengelola data

2. Pengunjung yangdapat mencari data informasi sekolah

3. Operator sekolah yang dapat melaporkan data prestasi sekolah

\section{ERD}


ERD (Entity Relationship Diagram) merupakan diagram yang dapat dijadikan pemodelan basis data relasional. Gambar 3 merupakan rancangan ERD yang digunakan pembuatan website.

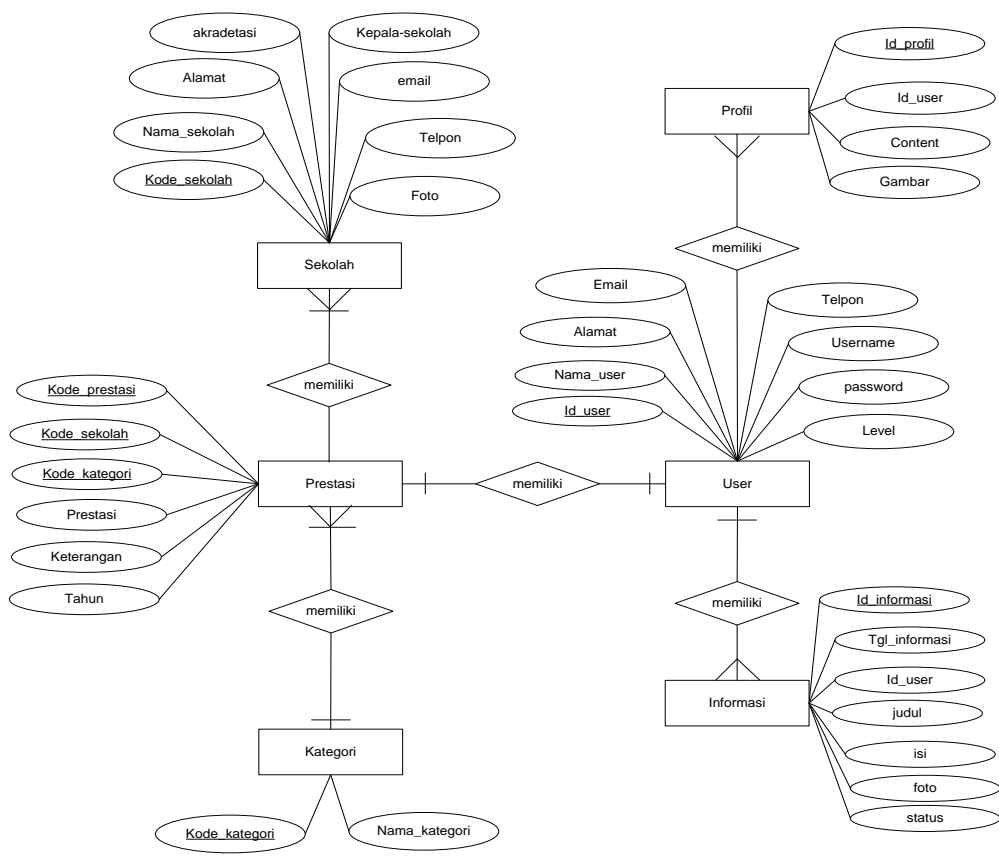

Gambar 3. ERD

\section{HASIL DAN PEMBAHASAN}

Hasil dari perancangan website menghasilkan halaman yang dapat diakses oleh pengguna.

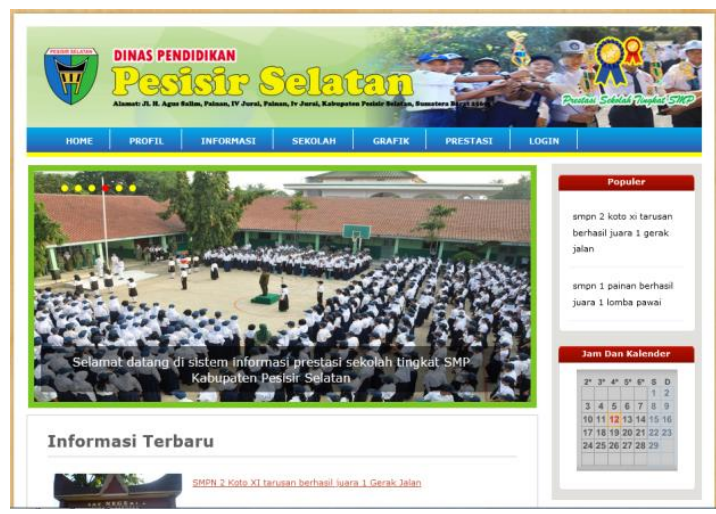

Gambar 4. Halaman Utama

Halaman utama merupakan halaman yang akan muncul ketika pengguna mengakses website tersebut seperti terlihat pada gambar 4 .

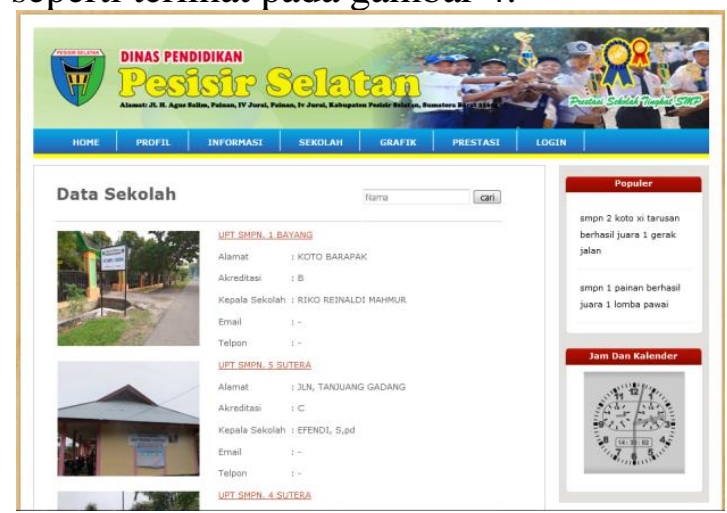

Gambar 5. Halaman Data Sekolah

Halaman data sekolah merupakan halaman yang menampilkan halaman terkait data informasi tentang sekolah. Halaman ini terlihat seperti pada gambar 5 .

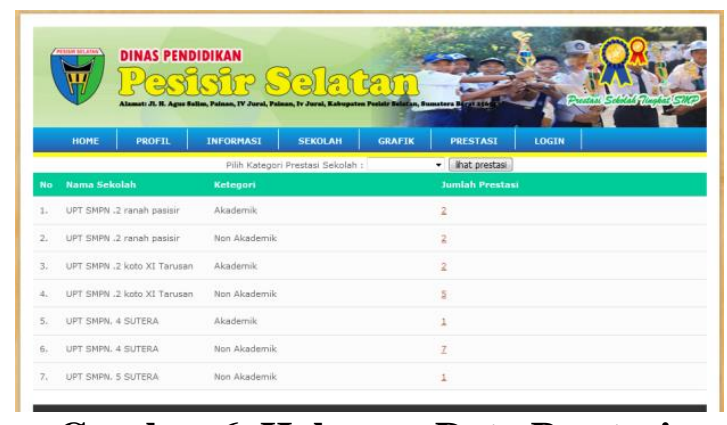

Gambar 6. Halaman Data Prestasi

Halaman data prestasi menampilkan data prestasi akademik dan non akademik yang dimiliki oleh setiap sekolah. Data yang dipakai yakni data yang dimiliki oleh Dinas Pendidikan Kabupaten Pesisir Selatan, seperti terlihat pada gambar 6.

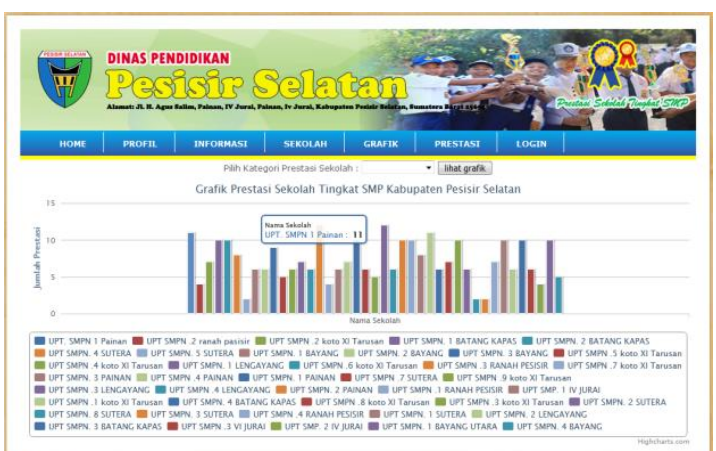

Gambar 7. Halaman Grafik Prestasi 
Halaman grafik data prestasi merupakan halaman untuk menampilkan visualisasi data prestasi dalam bentuk grafik. Visualisasi grafik dibedakan dengan warna

Website yang dirancang merupakan website yang akan dipakai oleh pengguna dan pihak Dinas Pendidikan. Maka dilakukan pengujian terhadap rancangan website kepada pengguna yang diambil secara acak.

Pengujian terhadap website bagi pengguna dilihat dari sisi fungsional website dan tampilan antar mukanya. Berdasarkan pengujian yang dilakukan maka diperoleh hasil dari sisi fungsional website sudah mampu menampilkan data prestasi akademik dan non akademik. Data prestasi yang ditampilkan sudah terkelompok dengan rinci.

Pengujian bagi pengguna juga dilakukan untuk menilai antar muka rancangan website. Berdasarkan pengujian maka diperoleh hasil bahwa antarmuka website secara keseluruhan sudah bagus dan nyaman unntuk dilihat. Penilaian yang kurang dilihat dari antarmuka halaman grafik data prestasi informasi yang disampaikan terlalu banyak sehingga sulit dibaca.

Perancangan antar muka bagi Dinas Pendidikan terlihat pada gambar 8 yang menampilkan halaman login Dinas Pendidikan ketika mengakses website tersebut.

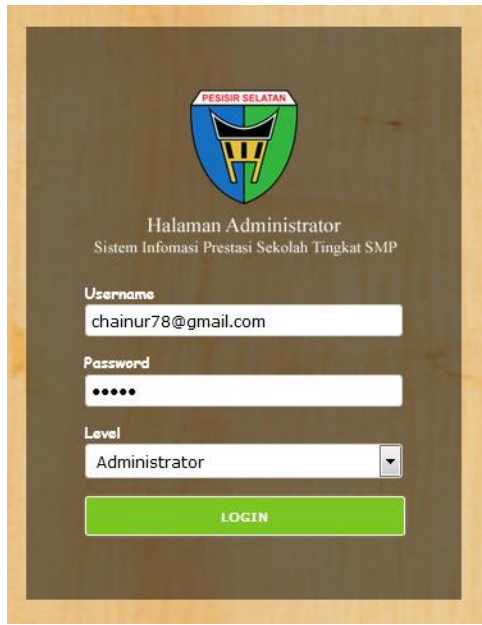

\section{Gambar 8. Halaman Login}

Antar muka yang tampil pada sisi admin adalah halaman yang dapat menambahkan data prestasi sekolah seperti terlihat pada gambar 9 .

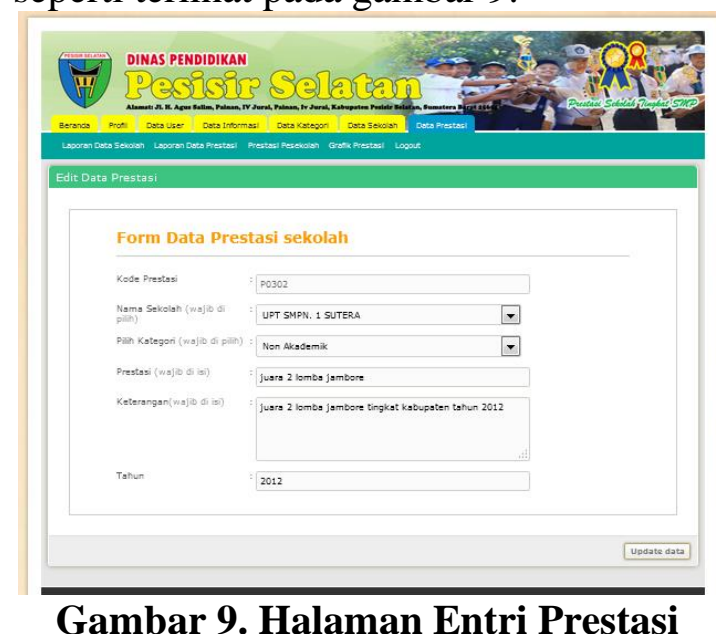

Pengujian yang dilakukan terhadap Dinas Pendidikan difokuskan pada fungsionalitas website yang dirancang yang dengan hasil bahwa fungsi dari setiap menu yang dirancang dapat dipergunakan dan mudah dimengerti dalam pengoperasiannya. Setiap menu yang ada mudah dipahami dan dipelajari.

\section{SIMPULAN}

Penelitian yang dilakukan dengan melihat pemanfaat rancangan website data prestasi sekolah menghasilkan simpulan bahwa rancangan sudah bagus dan nyaman digunakan serta fungsionalitas website dapat tercapai. Hasil diperoleh berdasarkan pengujian yang dilakukan terhadap pengguna dengan responden acak.

\section{DAFTAR PUSTAKA}

[1] Utomo, Wahyu Budi. 2013. Pembuatan web profil sekolah menengah pertama negeri 1 NGRAMPAL dengan menggunakan PHP dan MySql. Seminar Riset 
Unggulan Nasional Informatika dan Komputer, Vol 6 No 2.

[2] Jogiyanto. 2014. Analisis dan Desain Sistem. Yogyakarta : Andi.

[3] A.S, Rosa, Shalahuddin, M. 2013. Rekayasa Perangkat Lunak. Bandung: Informatika Bandung.
[4] Simarmata, Janner dan Paryudi, Iman. 2010. Basis Data. Yogyakarta : Andi.

[5] Akbar, Ginanjar. 2015. Website Profil Sekolah Sebagai Media Informasi Dan Promosi. Indonesian Journa of Network dan Security. Vol 4, No1. 